\title{
Study of the Concepts of Athletic Identity and Continuous Sport Self-Confidence in the Light of Various Variables
}

\author{
Mustafa Önder Şekeroğlu \\ Correspondence: Mustafa Önder Şekeroğlu, High School of Physical Education and Sports, Muş Alparslan University, \\ MUŞ, Turkey.
}

Received: November 26, 2017

Accepted: December 28, 2017

Online Published: December 29, 2017

doi:10.11114/jets.v5i13.2901

URL: https://doi.org/10.11114/jets.v5i13.2901

\begin{abstract}
This study was planned and conducted for the purpose of examining the relationship between the concepts of athletic identity and continuous sport self-confidence within the framework of various variables. The study group is comprised of 125 sportsmen of different branches, located at the Ankara Eryaman Olympics Preparation Centre. Along with a personal information form, the participants were subjected to the "Athletic Identity Scale" developed by Brewer and Cornelius (2001) in order to measure the athletic identity roles, as well as the "Continuous Sport Self-Confidence Scale," which is a sub-dimension of the measurement tool developed by Vealey (1986) in order to assess sport confidence. In this study, while no significant difference was found between the total points for continuous sport self-confidence according to gender, a significant difference was found between the athletic identity points. No statistically significant difference was found between the total points for continuous sport self-confidence and athletic identity according to their branches, number of national representation and their years of sport. In the meanwhile, it was found that $64 \%$ of the sportsmen in the research group were satisfied with their relations with their parents, while $52 \%$ were satisfied with their relations with their friends. It was found that $40 \%$ of the sportsmen were satisfied with how they used their spare time, and $48 \%$ were satisfied with their success in their studies.
\end{abstract}

Keywords: Olympic Preparation Centre, sport self-confidence, athletic identity

\section{Introduction}

It is a known fact that physical capacity alone is not enough in increasing sports performance and success, but psychological endurance and elements also have their share. For this reason, the importance of sports psychology increases by day. In all sports activities focusing on competition, there are psychological conditions and factors having a positive or negative impact on the performance and success of sportsmen.

In sports, self-confidence is considered a psychological factor that affects and determines performance (Vealey et al., 1998). The athletic identity, on the other hand, expresses a psychologically strong structure and, providing psychological benefits for sportsmen in general terms, affects sports life (Brewer et al., 1993).

Self-confidence is considered an important and necessary mental skill in sportsmen, as well as being an important factor having an impact on sports performance within the framework of thought and behaviour (Fletcher and Kanton, 2001; Jones and Hanton, 2001). Sport self-confidence is the sportsman's belief in themselves with regard to what they want to do and the targets they wish to achieve. Vealey (1986) distinguishes sport self-confidence as "Continuous Sport Self-confidence" and "Circumstantial Sport Self-confidence Continuous sportive self-confidence is expressed as individuals' general belief in their skills and abilities in order to succeed in sports. Circumstantial sportive self-confidence, however, is individuals' occasional belief in their skills and abilities in order to succeed in sports. Sport self-confidence is both a structure that depends on the circumstances according to many variables such as time, sportive discipline and the content of this discipline, the properties of the competition and the competitors, and a fixed property that is not affected by such circumstantial factors (Vealey, 1986).

Like all other personality traits, sport self-confidence has a multi-faceted and multi-dimensional structure. Accordingly, dimensions such as the sportsman's physical skills and practice, their ability to use psychological and perceptive skills, and their satisfaction with physical suitability are effective on sport self-confidence (Weinberger, 2003). Therefore, the concept of sport self-confidence, which has a multi-faceted structure, affects success and performance in turn. Research conducted suggests that one of the most important factors that affect performance in sports is sport self-confidence, 
which is among the most researched subjects in sport psychology, and is an important psychological process (Lirgg, 1991; Feltz et al., 2008).

The athletic identity represents the individual's perception and behaviour regarding sports events. It is the demonstration of the sports role presented along with the individual identity. This role is built up from the interaction between the sportsman's relations with others in social life, and their sports life (Brewer et al., 1993). The athletic identity may also be expressed as a social role. This role may be affected by trainers, teammates, family and the media. It also lends the individual a social status. Within mental processes, the athletic identity has an impact on the sportsman's strategies in coping, their decision-making and their behaviour (Pearlin, 1983; Horton and Mack, 2000).

In sports competitions, the mental endurance, stress conditions, sport self-confidence and strong athletic identity of sportsmen have an impact on their success and sports performance. This study, which is planned within this context, was conducted to examine the athletic identity and continuous sport self-confidence concepts in accordance with various variables.

\section{Materials and Method}

The study group is comprised of 125 sportsmen of different branches, located at the Ankara Turkey Olympics Preparation Centre. Along with a personal information form, the participants were subjected to the "Athletic Identity Scale" developed by Brewer and Cornelius (2001) in order to measure the athletic identity roles, as well as the "Continuous Sport Self-Confidence Scale" developed by Vealey (1986) in order to assess sport confidence. There are 10 question items in the Athletic Identity Scale, and 13 question items in the Continuous Sport Self-confidence Scale.

The screening method was used in this study, and the data obtained were analysed using the SPSS 23 package programme. The analysis of socio-demographic data was conducted through the percentage frequency analysis. The comparison of the binary variables was conducted through the independent test, while that of the multiple variables was conducted through a one-way analysis of variance Anova.

\section{Findings}

Table 1. Demographic Information on the Research Group

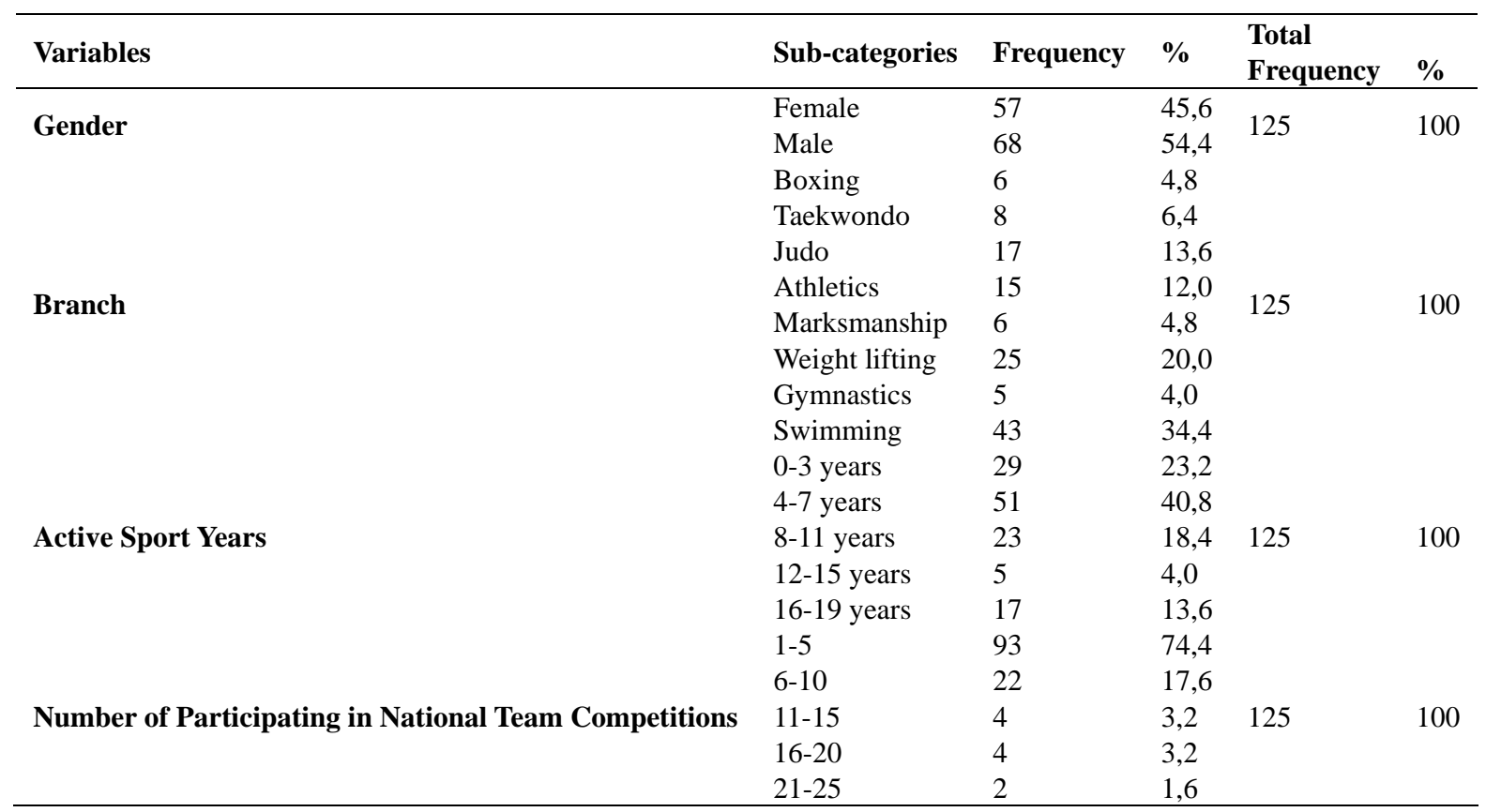

Of the sportsmen constituting the research group in Table 1, 54.4\% are men while $45.6 \%$ are women. Of these sportsmen, $4.8 \%$ are in boxing, $6.4 \%$ in taekwondo, $13.6 \%$ in judo, $12 \%$ in athletics, $4,8 \%$ in marksmanship, $20 \%$ in weight lifting, $4 \%$ in gymnastics, and $34.4 \%$ in swimming. $23,2 \%$ of the sportsmen have indicated to have been actively in sports for $0-3$ years, $40,8 \%$ for $4-7$ years, $18,4 \%$ for $8-11$, $4 \%$ for $12-15$ years, and $13,6 \%$ for $16-19$ years. Of the individuals participating in the study, 74,4\% have participated in national team competitions $1-5$ times, $17,6 \%$ 6-10 times, 3,2\% 11-15 times, 3,2\% 16-20 times and 1,6\% 21-25 times. 
Table 2. Participants' Satisfaction with their Relations with their Parents

\begin{tabular}{lll}
\hline & Frequency & \% \\
\hline Not satisfied at all & 2 & 1,6 \\
Not very satisfied & 3 & 2,4 \\
Satisfied & 40 & 32,0 \\
Very satisfied & 80 & 64,0 \\
Total & 125 & 100,0 \\
\hline
\end{tabular}

According to the table, examining the sportsmen's relations with their parents, $1,6 \%$ have replied as being not satisfied at all, 2,4\% as not very satisfied, $32 \%$ as satisfied, and $64 \%$ as very satisfied.

Table 3. Participants' Satisfaction with their Relations with their Friends

\begin{tabular}{lll}
\hline & Frequency & \% \\
\hline Not satisfied at all & 1 &, 8 \\
Not very satisfied & 6 & 4,8 \\
Satisfied & 65 & 52,0 \\
Very satisfied & 53 & 42,4 \\
Total & 125 & 100,0 \\
\hline
\end{tabular}

According to the analysis, examining the sportsmen's relations with their friends, $0,8 \%$ have replied as being not satisfied at all, $4,8 \%$ as not very satisfied, $52 \%$ as satisfied, and $42,4 \%$ as very satisfied.

Table 4. Participants' Satisfaction with How they Use their Spare Time

\begin{tabular}{lll}
\hline & Frequency & $\%$ \\
\hline Not satisfied at all & 3 & 2,4 \\
Not very satisfied & 27 & 21,6 \\
Satisfied & 50 & 40,0 \\
Very satisfied & 45 & 36,0 \\
Total & 125 & 100,0 \\
\hline
\end{tabular}

According to Table 4, 2,4\% of the individuals participating in the study indicate not being at all satisfied, $21,6 \%$ as not being very satisfied, $40 \%$ as being satisfied, and $36 \%$ as being very satisfied.

Table 5. Participants' Satisfaction with their Success in their Studies

\begin{tabular}{lll}
\hline & Frequency & \% \\
\hline Not satisfied at all & 5 & 4,0 \\
Not very satisfied & 20 & 16,0 \\
Satisfied & 60 & 48,0 \\
Very satisfied & 40 & 32,0 \\
Total & 125 & 100,0 \\
\hline
\end{tabular}

According to the above table, $4 \%$ of the individuals participating in the study indicate not being at all satisfied, $16 \%$ as not being very satisfied, $48 \%$ as being satisfied, and $32 \%$ as being very satisfied.

Table 6. Continuous Sport Self-confidence Scale Cronbach's Alpha Coefficient

\section{Reliability Statistics}

Cronbach's Alpha

0,881
$\mathrm{N}$ of Items

13

Table 7. Athletic Identity Scale Cronbach's Alpha Coefficient

\section{Reliability Statistics \\ Cronbach's Alpha}

0,870

In Tables 6 and 7, the Cronbach's Alpha analyses of the scales used in this study were carried out, and that of the Continuous Sport Self-confidence Scale was found as 0,881 , while that of the Athletic Identity Scale was found to be 0,870 . 
Table 8. The arithmetic mean and standard deviation values of the continuous sport self-confidence and athletic identity total points

\begin{tabular}{llll}
\hline & N & Average & $\begin{array}{c}\text { Standard } \\
\text { Deviation }\end{array}$ \\
\hline Continuous Sport Self-confidence total & 124 & 3,52 &, 64 \\
Athletic identity total & 125 & 4,05 &, 71 \\
\hline
\end{tabular}

Table 8 indicates the averages of the continuous sport self-confidence and athletic identity total points. According to the

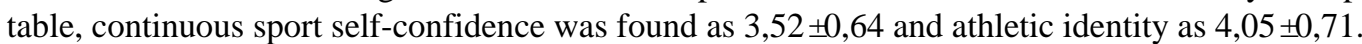

Table 9. Anova Analysis Results of Continuous Sport Self-confidence and Athletic Identity According to Gender

\begin{tabular}{lllllll}
\hline & Gender & $\mathbf{N}$ & Average & $\begin{array}{l}\text { Standard } \\
\text { Deviation }\end{array}$ & T & P \\
\hline \multirow{2}{*}{ Continuous Sport Self-confidence total } & Male & 68 & 3,58 &, 62 & 1,17 & $>0,05$ \\
& Female & 57 & 3,44 &, 67 & & \\
\multirow{2}{*}{ Athletic identity total } & Male & 68 & 3,94 &, 72 & $-1,90$ & $<0,05$ \\
\hline
\end{tabular}

According to Table 9, while no significant difference was found between the total points for continuous sport self-confidence according to gender, a significant difference of $\mathrm{p}<0,05$ was found between the athletic identity points.

Table 10. Anova Analysis Results of the Continuous Sport Self-confidence and Athletic Identity Total Points According to Branches

\begin{tabular}{|c|c|c|c|c|c|}
\hline & & $\mathbf{N}$ & Average & Standard Deviation $F$ & $\mathbf{p}$ \\
\hline \multirow{8}{*}{ Continuous Sport Self-confidence } & Boxing & 6 & 4,05 &, 12 & \multirow{8}{*}{$1,29>0,05$} \\
\hline & Taekwondo & 8 & 3,77 &, 52 & \\
\hline & Judo & 17 & 3,34 & 63 & \\
\hline & Athletics & 15 & 3,34 &, 34 & \\
\hline & Marksmanship & 6 & 3,44 & 62 & \\
\hline & Weight lifting & 25 & 3,58 & ,79 & \\
\hline & Gymnastics & 5 & 3,24 & ,68 & \\
\hline & Swimming & 42 & 3,53 & ,67 & \\
\hline \multirow{8}{*}{ Athletic identity } & Boxing & 6 & 4,36 &, 54 & \multirow{8}{*}{$1,96>0,05$} \\
\hline & Taekwondo & 8 & 4,35 &, 50 & \\
\hline & Judo & 17 & 4,41 & ,64 & \\
\hline & Athletics & 15 & 3,84 & ,68 & \\
\hline & Marksmanship & 6 & 4,20 & 1,00 & \\
\hline & Weight lifting & 25 & 4,12 &, 86 & \\
\hline & Gymnastics & 5 & 4,00 &, 44 & \\
\hline & Swimming & 43 & 3,82 & ,62 & \\
\hline
\end{tabular}

According to Table 10, no significant difference was found between continuous sport self-confidence and athletic identity total results according to branches $(\mathrm{p}>0,05)$. 
Table 11. Anova Analysis Results of the Continuous Sport Self-confidence and Athletic Identity Total Points According to the Number of National Representation

\begin{tabular}{|c|c|c|c|c|c|c|}
\hline & & $\mathbf{N}$ & Average & Standard Deviation & $\mathbf{F}$ & $\mathbf{P}$ \\
\hline \multirow{5}{*}{$\begin{array}{l}\text { Continuous } \\
\text { Self-confidence }\end{array}$} & $1-5$ & 92 & 3,47 & ,62 & \multirow{5}{*}{2,33} & \multirow{5}{*}{$>0,05$} \\
\hline & 6-10 & 22 & 3,62 & ,61 & & \\
\hline & Sport $_{11-15}$ & 4 & 3,23 & ,26 & & \\
\hline & $16-20$ & 4 & 3,63 & 1,10 & & \\
\hline & $21-25$ & 2 & 4,73 &, 16 & & \\
\hline \multirow{5}{*}{ Athletic identity } & $1-5$ & 93 & 4,01 & ,71 & \multirow{5}{*}{0,45} & \multirow{5}{*}{$>0,05$} \\
\hline & $6-10$ & 22 & 4,10 & ,77 & & \\
\hline & $11-15$ & 4 & 4,27 &, 53 & & \\
\hline & $16-20$ & 4 & 4,35 &, 75 & & \\
\hline & $21-25$ & 2 & 4,35 & ,35 & & \\
\hline
\end{tabular}

According to the anova analysis, no significant difference at the level of 0,05 was found between the total points of continuous sport self-confidence and athletic identity in relation to the number of national representation.

Table 12. Anova Analysis Results of the Continuous Sport Self-confidence and Athletic identity Total Points According to Active Sport Years

\begin{tabular}{|c|c|c|c|c|c|c|}
\hline & & $\mathbf{N}$ & Average & Standard Deviation & $\mathbf{F}$ & $\mathbf{p}$ \\
\hline \multirow{5}{*}{$\begin{array}{l}\text { Continuous } \\
\text { Self-confidence }\end{array}$} & $0-3$ years & $0-3$ years & 3,44 & ,71 & \multirow{5}{*}{0,16} & \multirow{5}{*}{$>0,05$} \\
\hline & 4-7 years & 4-7 years & 3,54 &, 59 & & \\
\hline & Sport $8-11$ years & $8-11$ years & 3,50 & 69 & & \\
\hline & $12-15$ years & $12-15$ years & 3,61 &, 75 & & \\
\hline & 16-19 years & $16-19$ years & 3,56 & ,63 & & \\
\hline \multirow{5}{*}{ Athletic identity } & $0-3$ years & $0-3$ years & 3,99 & 83 & \multirow{5}{*}{1,35} & \multirow{5}{*}{$>0,05$} \\
\hline & 4-7 years & 4-7 years & 4,19 & ,69 & & \\
\hline & $8-11$ years & $8-11$ years & 4,00 & ,69 & & \\
\hline & $12-15$ years & $12-15$ years & 4,18 &, 37 & & \\
\hline & $16-19$ years & $16-19$ years & 3,75 & ,60 & & \\
\hline
\end{tabular}

According to the anova analysis, no significant difference at the level of 0,05 was found between the total points of continuous sport self-confidence and athletic identity in relation to active sport years.

\section{Discussion}

Sport is a concept that develops individuals' understanding and sense of responsibility, encouraging them to act in cooperation. Along with this, it gives the individual the power to fit in with social groups and the community, harmonizing and strengthening individual-family, individual-community relations. At the same time, by contributing to personal development, sport also encourages the emergence of the individual's hidden talents. Sport is a concept that gives rise to the feeling of being appreciated by lending individuals an identity, role and status (Erkal et al., 1998; Dever, 2008). According to the findings of the study, $64 \%$ of the sportsmen in the research group were satisfied with their relations with their parents, while $52 \%$ were satisfied with their relations with their friends. It was found that $40 \%$ of the sportsmen were satisfied with how they used their spare time, and $48 \%$ were satisfied with their success in their studies. Humphrey's (1993) study showed that children participating in sports activities and doing sports are successful in their social relationships and studies. Therefore, social life and academic success increases the level of satisfaction.

No difference was found between gender and continuous sport self-confidence in the study. The study conducted by Öztürk et al. at the Trabzon Olympic Preparation Centre has also found no significant difference between sport self-confidence and gender. Other studies also indicate that the gender factor has no impact on self-confidence (Perry and Williams, 1998; Cox and Whaley, 2004). Within the context of sport self-confidence, Vealey (1988) identified that there was no significant difference based on gender among elite sportsmen displaying high and superior performance. It is seen that research that has been conducted support this research. However, there are also studies indicating that male sportsmen have a higher self-confidence compared to sportswomen (Crocker, 1989; Martens,1990; Jones et al., 1991; Krane and Williams, 1994; Petruzzeuo and Corbin, 1988).

The findings of the research have indicated to a significant difference between athletic identity and gender, and that 
gender plays an important role in determining the athletic identity. The athletic identity plays a social role within the framework of other individuals' perceptions, and the role of sport is demonstrated along with the individual identity. In this sense, the athletic identity that is related to the individual identity may be affected by individuals' gender roles. Examining the literature on the subject, research supporting the finding of this research were found (Brewer et al., 1993; VanRaalte and Cook, 1991; Weichman and Williams, 1997).

The research revealed no statistically significant difference between the sportsmen's active year in sports and the total scores for athletic identity. Examining similar studies on the subject, it is seen in Çetinkaya's (2015) study that there is no significant correlation between the duration of being a licenced sportsman and athletic identity. Oregon's (2010) study found that the length of an individual's time as a sportsman was not a factor that had an impact on the athletic identity. These results support the findings of this research. However, there are also studies indicating that athletic identity would become stronger with an increase in experience as a sportsman (Adler and Adler, 1991). Considering that athletic identity is affected by individual identity, social roles and environmental conditions, it is also possible that different results may emerge.

No significant difference was found between the branches of the sportsmen in the research group and athletic identity. While not many studies are seen on sports branches and athletic identity in the related literature, Çetinkaya's (2010, 2015) research indicates at different findings, showing that sports branches have an impact on athletic identity, and that the athletic identity of those occupied in team sports is dominant.

The research has found no significant difference between sportsmen's number of appearing at national team competitions, and athletic identity and continuous sport self-confidence. Therefore, it may be said that the level of athletic identity and sport self-confidence of the sportsmen participating in the study was not affected by their number of participation in national team competitions. Although representing their country on international platforms are a source of pride and self-confidence for sportsmen, it may be thought that the result that emerges in the study does not cause differences due to the profile of the study group as well as other factors.

No significant difference was found between the continuous self-confidence total scores according to sportsmen's branches and active sport years. In the literature, it is possible to see studies indicating that sports branches have no effect on determining sport self-confidence, thereby supporting the findings of this study (Fahiminezhad et al., 2004; Çetinkaya, 2015). It may be thought that this finding achieved under the study may stem from the social approach and perception towards sports branches, and the variety of sports branches. It was understood that the number of active sport years had no significant impact on sport self-confidence. Examining the literature on the subject, different findings are found in similar studies, and studies indicating that the number of active sports years and sports experience affect sport self-confidence (Brewer et al., 1993; Çetinkaya, 2015).

\section{Conclusion and Suggestions}

In conclusion, while no significant difference was found between the total points for continuous sport self-confidence according to gender, a significant difference was found between the athletic identity points. No statistically significant difference was found between the total points for continuous sport self-confidence and athletic identity according to their branches, number of national representation and their years of sport. In the meanwhile, it was found that $64 \%$ of the sportsmen in the research group were satisfied with their relations with their parents, while $52 \%$ were satisfied with their relations with their friends. It was found that $40 \%$ of the sportsmen were satisfied with how they used their spare time, and $48 \%$ were satisfied with their success in their studies.

An important concept considered to influence success in sports is the sportsman's performance. Among the psychological factors determining and impacting performance in sports, the concepts of athletic identity and sport self-confidence occupy an important place. In order that children and youths may experience a healthy sports life, their athletic identity must be strengthened, and they must be made to feel full sport self-confidence. The study may be applied to different variables in Olympic preparation centres in different provinces, thereby yielding different results, and such results may be shared with the concerned institutions in order to increase sportsman performance. In order that children and youths obtain an effective, productive and strong athletic identity and sport self-confidence, they must be supported by their families, PE teachers and trainers during elementary education, and the suitable environmental conditions must be provided. Taking into consideration that building up sport self-confidence and an athletic identity at an early age will have an impact on success and sports performance, this subject must be prioritised by corporations and institutions related to sports, and the necessary arrangements must be made.

\section{References}

Adler, P. A., \& Adler, P. (1991). Backboards and Blackboards, Columbia University, New York.

Brewer, B. W., \& Cornelius, A. E., (2001). Norms and factorial invariance of the Athletic Identity. Measurement Scale 
(AIMS), Academic Athletic Journal, 15, 103-113.

Brewer, B. W., VanRaalte J L., \& Linder, D. E. (1993). Athletic 1dentity: hercules' muscles or achilles heel?, International Journal of Sport Psychology, 24, 237-254,.

Çetinkaya, T. (2010). Factors Having an Impact on the Formation of the Sportsman Student Identity, Master's Thesis, Gazi University, Ankara. [In Turkish]

Çetinkaya, T. (2015). Relationship Between Athletic Identity and Continuous Sport Self-confidence in Team Sports, Doctoral Dissertation, Gazi University, Ankara. [In Turkish]

Cox, A. E., \& Whaley, D. E. (2004). The Influence Of Task Value, Expectancies For Success, And İdentity On Athletes' Achievement Behaviors, Journal of Applied Sport Psychology, 16,103-117. https://doi.org/10.1080/10413200490437930

Crocker, P. R. E. (1989). A Follow-Up Of Cognitive-Affective Stress Management Training, Journal of Sport Exercise Psychology, 11, 236-242. https://doi.org/10.1123/jsep.11.2.236

Dever, A. (2008). Sports in its Sociological Dimensions, Master's Thesis, Cumhuriyet University, Sivas. [In Turkish]

Erkal, M. E., Güven, Ö., \& Ayan, D. (1998). Sports from a Sociological Point of View, Der Yayınları, Istanbul. [In Turkish]

Fahiminezhad, A., Khani, S., \& Ghasemi, A. (2014). The Comparison Of Sport Confidence (Trait, State, And Sports) Between Young Athletes İn İndividual And Team Sports İn Shahrood City, European Journal of Experimental Biology, 4(3), 458-462.

Feltz, D. L., Sandra, E. S., \& Sullivan, P. J. (2008). Self-Efficacy İn Sport, Human Kinetics Boks, Champaign, IL.

Fletcher, D., \& Kanton, S., (2001). The Relationship Betvveen Psychological Skills Usage And Competitive Arodety Responses, Psychology of Sport and Exercise, 2, 89-101. https://doi.org/10.1016/S1469-0292(00)00014-5

Horton, R. S., \& Mack, D. E. (2000). Athletic İdentity İn Marathon Runners: Functional Focus Or Dysfunctional Commitment?, Journal of Sport Behavior, 23, 101-119.

Humphrey, J. H. (1993). Sports for Children: A Guide for Adults, Charles C. Thomas Publisher, Springfield.

Jones, G., \& Hanton, S. (2001). Pre-Competitive Feeling States And Directional Anxiety İnterpretations, Journal of Sports Sciences, 19, 385-395. https://doi.org/10.1080/026404101300149348

Jones, G., Swain, A., \& Cale, A. (1991). Gender Differences İn Precompetition Temporal Patterning And Antecedents Of Anxiety And Self-Confidence, Journal of Sport \& Exerdse Psychology, 13, 1-15. https://doi.org/10.1123/jsep.13.1.1

Krane, V., \& Williams, J. M. (1994). Cognitive Anxiety, Somatic Anxiety and Confidence in Track and Field Athletes: The Impact of Gender, Competitive Level and Task Characteristics, Journal of Sport Psycholog, 25, $203-217$.

Lirgg, C. D. (1991). Gender Differences İn Self-Confidence İn Physical Activity: A Metaanalysis Of Recent Studies, Journal of Sport and Exercise Psychology, 8, 294-310. https://doi.org/10.1123/jsep.13.3.294

Martens, R. (1990). Successfitl Coaching, Second Edition, Leisure Press, Champaign, III inois, U.S.A.

Oregon, E. M., (2010). An Examination Of Athletic İdentity And İdentity Foreclosure Among Male Collegiate Student-Athlete. Doctoral Dissertation, Harris Hall. The Unıversity Of North Carolına.

Öztürk, A., Bayazit, B., \& Gencer, E. (2016). An Examination of the Problem-solving Skills and Sport Self-confidence levels of Judo practitioners (Trabzon Olympic Preparation Centre Example)", Ankara University Faculty of Sports Sciences, 14 (2), 145-151, [In Turkish]

Pearlin, L. I. (1983). Role strains and personal stress. (HB Kaplan,Ed.), Psychosocial Stress: Trends in Theory and Research Academic Press. New York.

Perry, J. D., \& Williams, J. M. (1998). Relationship Of İntensity And Direction Of Competitive Trait Arutiety To Skill Level And Gender İn Tennis, The Sport Psychologist, 12, 169-179. https://doi.org/10.1123/tsp.12.2.169

Petruzzeuo, S. J., \& Corbin, C. B. (1988). The Effects Of Performance Feedback On Female Self-Confidence., Journal of Sport \& Exercise Psychology, 10,174-183. https://doi.org/10.1123/jsep.10.2.174

Van Raalte, J. L., \& Cook, R. G. (1991). Gender Specific Situational İnfluences On Athletic İdentity. Paper Presented At The Annual Meeting Of The North American Society For The Psychology of Sport and Physical Activity, Monterey, California. 
Vealey, R. S. (1986). Coceptualization Of Sport Confidence And Competitive Orientation: Preliminary İnvestigation And İnstrument Development, Journal Of Sport Psychology, 8, 221-246. https://doi.org/10.1123/jsp.8.3.221

Vealey, R. S. (1988). Sport-Confidence And Competitive Orientation: An Addendum On Scoring Procedures And Gender Differences, Journal Of Sport \& Exercise Psychology, 471-478. https://doi.org/10.1123/jsep.10.4.471

Vealey, R. S., Hayashi, S. W., Garner, H. M., \& Giacobbi, P. (1998). Sources Of Sportconfidence: Conceptualization And İnstrument Development, Journal of Sport \& Exercise Psychology, 20(1), 54-80. https://doi.org/10.1123/jsep.20.1.54

Weinberger, R. S. (2003). Foundation Of Sport And Exercise Psychology, Human Kinetics, Champaign, IL.

Wiechman, S. A., \& Williams, J. (1997). Factors Affecting Athletic İdentity And Expectations İn The High School Student Athlete, Journal of Sport Behavior, 20, 199-211.

\section{Copyrights}

Copyright for this article is retained by the author(s), with first publication rights granted to the journal.

This is an open-access article distributed under the terms and conditions of the Creative Commons Attribution license which permits unrestricted use, distribution, and reproduction in any medium, provided the original work is properly cited. 